\title{
Window Shopping Learning Model on Islamic Education and Creative-Collaborative Skill Improvement
}

\author{
Mumu Abdurrohman, Dindin Nasrudin*, Aep \\ Saepurrohman, Irfan Ahmad Zein \\ Faculty of Tarbiyah and Teacher Training \\ UIN Sunan Gunung Djati \\ Bandung, Indonesia \\ *dindin.nasrudin@uinsgd.ac.id
}

\author{
Imas Kurniati \\ Junior High School 2 Cileunyi \\ Bandung, Indonesia
}

\begin{abstract}
In the modern era, Islamic Education (IE) for adolescents does not have to use a dogmatic approach. Creative efforts are needed to make religious learning not only effective but also enjoyable. This research would like to reveal the results of qualitative analysis of the IE's learning process by using windows shopping learning model. The research method is qualitative descriptive. The results of the research are (1) Analysis of basic competence on one of IE's topics (2) Analysis of creative thinking skill indicator (3) Analysis of collaborative skills indikator and (4) Design of Islamic learning by using window shopping. This study concludes that through learning window shopping, learners are facilitated to develop creative-collaborative thinking skills that impact on Islamic learning more flexible, interactive and fun without reducing the substance and basic competence desired. More quantitative follow-up research is needed to measure improvements in the creative-collaborative skills of the learners.
\end{abstract}

Keywords - creative-collaborative skill; islamic education; window shopping

\section{INTRODUCTION}

In recent years, world education has grown by renewing its focus on high-level skills including Islamic education. In this 21 st century, in addition to mastering the concept and application, education is directed to prepare the young generation in the face of an increasingly complex world [1]. There are seven 21 st century skills that must be mastered by learners: technical, information management, communication, collaboration, creativity, critical thinking and problem solving [2]. Achieving these seven skills should be facilitated by learning in the classroom and familiarized in daily life [3]. Learning that is designed in a situation that is close to the actual situation, will facilitate the ability of learners in the face of similar things in the future.

In the context of Indonesia, Islamic Education is often addressed for three things, namely Islamic Education as an institution, Islamic Education as a subject, and Islamic Education as a value [4]. In this study, Islamic Education is seen as a subject. Islamic Education lessons in junior high school have the role of preparing learners to be members of the community who have the ability to establish mutual relationships with the surrounding social, cultural and natural environment [5].

Both as a subject and as a value, in general, Islamic Education contains three main things, namely aqidah, ibadah and akhlaq [6]. Mastery of the three basic things must be a practice in everyday life, not just mastery of the concept alone. Even by studying and implementing the teachings it is expected to be a driver and complement the mastery of 21 st century skills.

Two 21st century skills considered relevant and in line with Islamic Education are creative and collaborative thinking skills. Creativity is a prerequisite for a person to be able to survive in this era. Without the ability to think creatively, one can not be a competitor to another and always lags behind [7]. Similarly, the ability of collaboration is considered important in stimulating a person in considering the development and use of knowledge for new things with his team [8]. One of the prerequisites for achieving these two skills is if the school develops into a learning organization with a collective learning process and shared learning outcomes, where pupils, teachers, and principals develop their 21st-century skills [9]. One of the learning models considered suitable for developing creative and collaborative thinking skills is the window shopping model.

Window Shopping by oxford dictionary "The activity of looking at goods displayed in a windows shop, especially without intending to buy anything" [10]. This term is often used in buying and selling terms and is often referred to as "show rooming". One of the writings discussing the term is Oz Shy's research [11]. In the context of learning, window shopping is defined as student learning activities by "shopping" or "seeing, reading, and observing" information or topics presented by other groups.

Window shopping is a learning model that can be used to train students' collaboration and thinking skills because each student is required to have skills in delivering the topics that his group discusses to the end who attends to his stand [12]. Characteristic of doing a traveling activity looking at the work of other groups, this model is believed to increase students' creative thinking skills and create pleasant situations but still be effective as the learning objectives achieved [13]. The purpose 
of this paper is to describe the design of Islamic Education learning by using a window shopping model that facilitates learners to improve their creative thinking and collaborative skills.

\section{METHOD}

This research is preliminary research by using a qualitative descriptive method. The main objective is to get the Islamic Education learning design using window shopping model that facilitates the achievement of creative thinking skills and collaborative skills. This research begins with analyzing the Core Competencies and Basic Competencies on the curriculum of Islamic Education on one subject, analyzing the indicators of creative-collaborative thinking skills of the experts and outlining the design of Islamic learning using the window shopping model.

Curriculum analysis is considered very important to do considering the learning of Islamic Education in schools must follow the signs of the curriculum. Without a better curriculum, better teaching, and better tests, an emphasis on "21-st century skills" would be a superficial one that would sacrifice long-term gains for short-term progress appearances [14]. Considering that, educational practitioners compete to make various learning models

The development of learning model is done in order to increase the effectiveness of learning to achieve learning objectives. In this study, we selected one of the subjects contained in the syllabus of Islamic Education at the secondary school level namely Asmaul Husna: al-'Alim, al-Khabir, asSami ', and al-Bashir. After the subject matter is determined, the next step is to mapping the expected competencies i.e. indicators of creative thinking and collaborative skills.

Learning that leads to the improvement of creative thinking skills is a method of teaching that focuses on the discovery of new products, ideas, original discoveries, re-elaboration, or improving existing products [15]. While learning that facilitates the enhancement of collaborative skills means a method of teaching where learners come together to learn as a group and help each other to achieve certain learning targets [16, 17]. Through Focus Group Discussion (FGD) fellow researchers finally obtained the learning design of Islamic Education which facilitates the improvement of creative thinking and collaborative skills.

\section{RESULT AND DISCUSSION}

\section{A. Core Competence and Basic Competence of Islamic}

Education on the Subject of Asma al-Husna (al-'Alim, alKhabir, as-Sami', and al-Bashir)

The use of window shopping model in the subject of Islamic Education begins with curriculum analysis. The table shows the core competencies and basic competencies on one subject: Asmaul Husna. The core competencies listed in the syllabus are not to be taught, but to be formed through the learning of relevant subjects. Each subject must be subject to core competencies that have been formulated [18]. Meanwhile, basic competence is a number of minimal abilities that must be mastered learners after following the learning on certain subjects. Basic competence is used as a reference for the preparation of competency indicators in a lesson [19].

The K-13 integrates three competency domains, namely attitudes, knowledge, and skills which in its implementation are summarized in KI-1 (spiritual attitudes), KI-2 (social attitudes), KI-3 (knowledge), and KI-4 (skills) [20].

TABLE I. CORE COMPETENCIES AND BASIC COMPETENCIES ON THE SubJECT Of ASMA AL-HuSNA: $A L-' A L I M, A L-K H A B I R, A S-S A M I$ ', AND $A L-$ BASHIR

\begin{tabular}{|c|c|c|}
\hline & Core Competencies (KI) & Basic Competencies (KD) \\
\hline 1 & $\begin{array}{l}\text { Appreciate and live the religious } \\
\text { teachings he embraces }\end{array}$ & $\begin{array}{l}\text { 1.3 Believing that Allah } \\
\text { SWT. All knowing, All- } \\
\text { Vigilant, All-Hearing, and } \\
\text { All-Seeing }\end{array}$ \\
\hline 2 & $\begin{array}{l}\text { Demonstrate honest behavior, } \\
\text { discipline, responsibility, care } \\
\text { (tolerant, mutual assistance), } \\
\text { courteous, confident in } \\
\text { interacting effectively with the } \\
\text { social and natural environment } \\
\text { within the reach of the } \\
\text { association and its existence }\end{array}$ & $\begin{array}{l}\text { 2.3. Demonstrate confident, } \\
\text { diligent, conscientious, and } \\
\text { hard work as the } \\
\text { implementation of the } \\
\text { meaning of al-'Alim, al- } \\
\text { Khabir, as-Sami ', and al- } \\
\text { Bashir }\end{array}$ \\
\hline 3 & $\begin{array}{l}\text { Understanding the knowledge } \\
\text { (factual, conceptual, and } \\
\text { procedural) based on his } \\
\text { curiosity about science, } \\
\text { technology, art, culture-related } \\
\text { phenomena and eye-catching } \\
\text { events }\end{array}$ & $\begin{array}{l}3.3 \text { Understanding the } \\
\text { meaning of al-Asma'u al- } \\
\text { Husna: al-'Alim, al-Khabir, } \\
\text { as-Sami ', and al-Bashir }\end{array}$ \\
\hline 4 & $\begin{array}{l}\text { Trying, processing, and serving } \\
\text { in a concrete realm (using, } \\
\text { parsing, composing, modifying, } \\
\text { and making) and abstract realm } \\
\text { (writing, reading, computing, } \\
\text { drawing and composing) as } \\
\text { learned in school and other } \\
\text { sources in the same viewpoint } \\
\text { /theory }\end{array}$ & $\begin{array}{l}\text { 4.3 Presents examples of } \\
\text { behaviors that reflect those } \\
\text { who emulate al-Asma'u al- } \\
\text { Husna: al-'Alim, al-Khabir, } \\
\text { as-Sami ', and al-Bashir }\end{array}$ \\
\hline
\end{tabular}

Based on table I above, the material of Asmaul Husna is not only delivered through lectures by reading only. Moreover, Asmaul Husna (the good name of God) must be understood (KI3) must be manifest in everyday attitude (KI1 and KI2) and actualized in real action (KI4). For example, the name of the god Al-Bashir (All Seeing)) is not only known and he said, but must be a spirit for learners that every movement is always seen by He who sees. If they already feel seen by their Lord, then they will always do well to others and will not dare to make mistakes. In order for learners to arrive at that ability, active, innovative and contextual learning is needed, one of which is window shopping model.

\section{B. Creative Thinking Skill Indicator}

Many experts suggest indicators of creative thinking skills. Until now, there is still no single theory of creative thinking that is really accepted by all researchers. Having learned the complexity of the construction of creative thinking and its various manifestations in everyday life, it seems impossible to appear "a general theory" [21]. Among the experts who revealed indicators of creative thinking skills were Guilford [22] and Williams [23]. Table II below is an indicator of creative thinking skills expressed by Williams (1979). 
The achievement of the indicator of creative thinking skills proposed by William will be facilitated in Islamic learning through window shopping model. For example, in order for the learner to come up with his original idea, he is trained to answer any questions given by his friends from other groups. The harder and more complex the question, the answers from our students will be more original.

TABLE II. CREATIVE THINKING SKILL ON WINDOW SHOPING LEARNING MODEL ACTIVITY

\begin{tabular}{|c|l|l|}
\hline \multicolumn{1}{|c|}{$\begin{array}{c}\text { Skill Category } \\
\text { (Williams, }\end{array}$} & \multicolumn{1}{c|}{$\begin{array}{c}\text { Creative Thinking Skill } \\
\text { Skills on Window Shopping Learning } \\
\text { Model Activity }\end{array}$} \\
\hline 1 & fluency & $\begin{array}{l}\text { Students are asked to develop as many } \\
\text { questions as possible about the given picture }\end{array}$ \\
\hline 3 & flexibility & $\begin{array}{l}\text { Students are asked to develop as many } \\
\text { answers as possible to the questions given by } \\
\text { their friends The answer given is not } \\
\text { textbook, but the result of understanding }\end{array}$ \\
\hline 4 & elaboration & $\begin{array}{l}\text { Students are asked to express opinions about } \\
\text { a case or event related to the theme of the } \\
\text { lesson }\end{array}$ \\
\hline 5 & $\begin{array}{l}\text { Students are required to disclose the best and } \\
\text { outstanding ways to improve the information } \\
\text { provided into more precise and } \\
\text { understandable information }\end{array}$ \\
\hline
\end{tabular}

\section{Collaborative Skill Indicator}

Collaborative skills are needed in many contexts such as school, workplace, even in the military. These skills are potentially effective for improving learning outcomes and performance [24]. The collaborative skills to be developed in Islamic learning refers to the indicator put forward by Bosworth [25]. Table III below shows five indicators of collaboration skills from Bosworth, namely interpersonal skills, group building/management, inquiry skills, conflict, and presentation.

TABLE III. COLLABORATIVE SKILL ON WINDOW SHOPING LEARNING MODEL ACTIVITY

\begin{tabular}{|c|l|l|}
\hline & Skill Category & \multicolumn{1}{c|}{$\begin{array}{c}\text { Collaborative } \\
\text { Skills on Window Shopping Learning } \\
\text { Model Activity }\end{array}$} \\
\hline 1 & $\begin{array}{l}\text { Interpersonal } \\
\text { skills }\end{array}$ & $\begin{array}{l}\text { Learning actitivity facilitates students to } \\
\text { become individuals with the following } \\
\text { characteristics:congenial, friendly, make } \\
\text { clear statements, positive communication, } \\
\text { eye contact, listening skills (no name } \\
\text { calling, put-downs) }\end{array}$ \\
\hline 2 & $\begin{array}{l}\text { Group } \\
\text { ement }\end{array}$ & $\begin{array}{l}\text { Organize work, Keep group on task, Run a } \\
\text { meeting, Participate in group self-analysis } \\
\text { and Show empathy }\end{array}$ \\
\hline 4 & Inquiry skills & $\begin{array}{l}\text { Clarification Critique, Probe assumptions } \\
\text { and evidence, Probe implication \& } \\
\text { consequences, Elicit viewpoints \& } \\
\text { perspectives }\end{array}$ \\
\hline 5 & Presentation & $\begin{array}{l}\text { Summarize, synthesize Speaking in front of } \\
\text { a group Creating presentation materials } \\
\text { Report writing }\end{array}$ \\
\hline
\end{tabular}

Collaborative skills are needed by everyone in this era. Without collaboration, we will be left behind by the progress of others. Islamic education has an important role in encouraging, supporting and facilitating the achievement of these skills. In fact, Islamic Education can provide reinforcement through the arguments contained in the holy book so as to encourage the learners to apply it.

\section{Design of Islamic Education Learning by using Window Shopping}

After analyzing the needs of curriculum and competencies that are expected to be complemented by indicators of creative and collaborative thinking skills, the latest step of this research is the design of learning delays. The learning steps using window shopping model shown in Table IV.

TABLE IV. WINDOW SHOPPING LEARNING MODEL STEPS

\begin{tabular}{|c|c|}
\hline No & Learning Steps \\
\hline 1 & Students are made into groups \\
\hline 2 & $\begin{array}{l}\text { The teacher distributes different questions to each group. Problems } \\
\text { received by students are questions designed to train students' creative } \\
\text { and collaborative thinking skills. }\end{array}$ \\
\hline 3 & $\begin{array}{l}\text { In groups students work together on the questions teachers have } \\
\text { given. The result of the problem is written on a piece of cardboard } \\
\text { or the like. In this activity, the teacher provides guidance as } \\
\text { necessary. }\end{array}$ \\
\hline 4 & $\begin{array}{l}\text { The work of each group is then displayed on the wall around the } \\
\text { classroom. This activity is likened to open shop. Of course with the } \\
\text { problem-solving as a display. }\end{array}$ \\
\hline 5 & $\begin{array}{l}\text { Duty distribution of each group. There are members of the group } \\
\text { who are in charge of looking after the shop and others walking } \\
\text { around to visit other group stores }\end{array}$ \\
\hline 6 & $\begin{array}{l}\text { Students as shopkeepers are expected to give explanations to other } \\
\text { group members who need an explanation regarding the completion } \\
\text { of the displays. It is recommended to choose a guard who is able to } \\
\text { communicate well and understand the results of group work. In this } \\
\text { activity the emergence of peer tutor activities. }\end{array}$ \\
\hline 7 & $\begin{array}{l}\text { For group members who visit other groups in addition to being } \\
\text { eligible for an explanation, they are also entitled to provide input and } \\
\text { correction to the work of the group they visit by writing it on the } \\
\text { group's worksheet. The visiting group recorded the work of the } \\
\text { visited group }\end{array}$ \\
\hline 8 & $\begin{array}{l}\text { After the specified time is over, each member returns to the initial } \\
\text { group }\end{array}$ \\
\hline 9 & $\begin{array}{l}\text { After returning group members exchange information based on the } \\
\text { results of visits that have been done. }\end{array}$ \\
\hline 10 & $\begin{array}{l}\text { The teacher then goes around checking the work and looking at } \\
\text { things that need improvement and commenting on the work of each } \\
\text { group. }\end{array}$ \\
\hline 11 & $\begin{array}{l}\text { The teacher confirms feedback and correction of classical group-type } \\
\text { work. }\end{array}$ \\
\hline 12 & $\begin{array}{l}\text { To find out the students' understanding of the quiz individually with } \\
\text { the same type of problem with the problems that have been done by } \\
\text { all groups }\end{array}$ \\
\hline
\end{tabular}

The above learning steps are standard procedure of applying window shopping model. In practice, a teacher can bring learning activities more flexible, natural and fun. However, the learning objectives of each subject must remain the main objective.

\section{CONCLUSION}

In the era of the $21 \mathrm{st}$ century, Islamic education learning should be designed more innovatively. Learning activities are not only aimed at achieving curriculum demands 
but also should be directed to the achievement of 21-st century skills, one of which is creative and collaborative thinking skills.

Through curriculum analysis, creative-collaborative skill indicators and instructional design, window shopping models are believed to be an alternative in facilitating learners to develop their creative-collaborative thinking skills. Application of window shopping model will make the learning of Islam more interesting, fun and present.

\section{ACKNOWLEDGMENT}

Acknowledgments are conveyed to the Dean of the Faculty of Tarbiyah and Teacher Training for the facility in presenting this paper and to all parties who assist in the preparation of this paper.

\section{REFERENCES}

[1] P. Ellerton, On critical thinking and collaborative inquiry. Forthcoming, and to be presented at the SFU critical thinking round table in February. 2018.

[2] E. van Laar, A.J. van Deursen, J.A. van Dijk, and J. de Haan, J., "The relation between 21 st-century skills and digital skills: A systematic literature review," Computers in human behavior, vol. 72, pp. 577-588, 2017.

[3] B. Trilling, and C. Fadel, 21st century skills: Learning for life in our times. John Wiley \& Sons, 2009.

[4] H. Haidar Putra Daulay MA, Pendidikan Islam dalam sistem pendidikan nasional di Indonesia. Kencana, 2014 Jul 1.

[5] J.A. Feisal, Reorientasi Pendidikan Islam. Gema Insani, 1995.

[6] S.H. Hamjah, and N.S. Akhir, "Islamic approach in counseling," Journal of religion and health, vol. 53, no. (1), pp. 279-89, 2014.

[7] H.S. Tanjung, "Perbedaan Kemampuan Berpikir Kreatif dan Pemecahan Masalah Matematis Siswa dalam Penerapan Model Pembelajaran Berbasis Masalah," Genta Mulia: Jurnal Ilmiah Pendidikan, vol. 9, no. (1), 2018 .

[8] S. Zubaidah, Keterampilan abad ke-21: Keterampilan yang Diajarkan melalui Pembelajaran. Disampaikan pada Seminar Nasional Pendidikan dengan Tema "Isu-isu Strategis Pembelajaran MIPA Abad, 2016.
[9] F. Basten, A. Evers, F. Geijsel, and M. Vermeulen, 21st Century leadership skills for learning networks.

[10] https://en.oxforddictionaries.com/definition/window shopping

[11] Oz. Shy, "Window shopping." 2014.

[12] J.E. Palunsu, Suwanti, D.S. Indrawati, and S.L. Saraswati, Pengembangan Profesi Program Sekolah Pembelajar. Kemendikbud: Direktorat Jenderal Guru dan Tenaga Kependidikan, 2016.

[13] W. Rahma, "Pengaruh Penggunaan Metode Kooperatif Window Shopping terhadap Partisipasi Bimbingan Konseling Klasikal," Jurnal Penelitian Pendidikan Indonesia, vol. 2, no. (2), 2017.

[14] A.J. Rotherham and D.T. Willingham "21st-Century" skills. American Educator, 2010, pp. 17.

[15] L.S. Almeida, L.P. Prieto, M. Ferrando, E. Oliveira, C. Ferrándiz, "Torrance Test of Creative Thinking: The question of its construct validity," Thinking skills and creativity, vol. 3, no. (1), 53-8, 2008.

[16] T. Panitz, Collaborative versus CooperativeLearning: A Comparison of the Two Concepts, 1999.

[17] R.E. Slavin, "Cooperative Learning and Academic Achievement: Why Does Groupwork Work?" Anales de Psicología/Annals of Psychology, vol. 30, no. (3), pp. 785-791, 2014.

[18] M. Nuh, "Kurikulum 2013." Sumber: http://www. kemdiknas. go. id 2013.

[19] Pendidikan, Badan Standar Nasional. "Standar Proses untuk Satuan Pendidikan Dasar dan Menengah." Badan Standar Nasional Pendidikan, 2007.

[20] I. Machali, "Kebijakan Perubahan Kurikulum 2013 dalam Menyongsong Indonesia Emas Tahun 2045." Jurnal Pendidikan Islam vol. 3, no. 1 pp. 71-94, 2014.

[21] D.K. Filsaime, Menguak Rahasia Berpikir Kritis dan Kreatif. Jakarta: Prestasi Pustaka, 2008.

[22] J.P. Guilford, "Factors that aid and hinder creativity," Teachers College Record, vol. 63, pp. 380-392, 1962.

[23] F.E. Williams, "Assessing creativity across Williams" cube" model," Gifted Child Quarterly, vol. 23, no. (4), pp. 748-56, 1979.

[24] Andrews, Jessica J., et al. "Modeling Collaborative Interaction Patterns in a Simulation-Based Task." Journal of Educational Measurement, vol. 54 no. 1, pp. 54-69, 2017.

[25] K. Bosworth, "Developing collaborative skills in college students," New directions for teaching and learning, no. (59), pp. 25-31, 1994. 